\title{
Potential Antiaging Effects of DLBSI649, a Centella asiatica Bioactive Extract
}

\author{
Agung $\mathrm{H}$ Karsono (D) \\ Olivia M Tandrasasmita' \\ Guntur Berlian' \\ Raymond R Tjandrawinata ${ }^{2,3}$ \\ 'Section of Molecular Pharmacology, \\ Research Innovation and Invention, Dexa \\ Laboratories of Biomolecular Sciences, \\ Dexa Medica, Cikarang, West Java I7550, \\ Indonesia; ${ }^{2}$ Dexa Laboratories of \\ Biomolecular Sciences, Dexa Medica, \\ Cikarang, West Java 17550, Indonesia; \\ ${ }^{3}$ Faculty of Biotechnology, Atma Jaya \\ Catholic University of Indonesia, \\ Tangerang, I5345, Indonesia
}

Purpose: Centella asiatica is a traditional medicinal plant, especially for wound healing and as a neuroprotective agent. DLBS1649 is a bioactive extract from C. asiatica, and was studied to investigate its benefits as an antiaging agent.

Methods: DLBS1649 was administered to HEK293 and 3T3L1 mammalian cells cultured in a time- or dose-dependent manner. Telomere length analysis was performed. TERT, CMYC, SIRT1, SIRT2, and KL expression were observed using reverse-transcription qPCR. Telomerase protein was studied with ELISA, while calorie restriction was observed using Oil Red O. In vivo study was conducted using Drosophila melanogaster with restricted mean survival time as the statistical method of analysis.

Results: DLBS1649 $50 \mu \mathrm{g} / \mathrm{mL}$ showed an effect in the prevention of telomere shortening by $50 \%$ and decrease in telomerase activity by $28 \%$ compared to the controls $(70 \%$ and $40 \%$, respectively) in the HEK293 cell cultures. TERT-, CMYC-, SIRT1-, SIRT2-, and KL-expression degression was also reduced $(29 \%, 9 \%, 18 \%, 25 \%, 9 \%$, and $30 \%$, respectively) compared to the controls $(46 \%, 40 \%, 56 \%, 44 \%$, and $46 \%$, respectively) after ten serial passages. Calorie-restriction activity from DLBS1649 $50 \mu \mathrm{g} / \mathrm{mL}$ was seen, with lower fat droplet counts being detected in the treated samples (37\%) than the controls $(28 \%)$ in 3T3L1 cells. DLBS1649 $2 \mathrm{mg} / \mathrm{mL}$ increased restricted mean survival time in male and female $D$. melanogaster (23.87\% $[p<0.05]$ and $12.58 \%$, respectively).

Conclusion: The results revealed DLBS1649's potential as an antiaging agent based on telomere-length preservation, decreased expression of aging-related genes, increased calorie restriction in vitro, and mortality reduction in D. melanogaster in vivo.

Keywords: herbal, TERT, SIRT, klotho, fruit flies, mortality

\section{Introduction}

Increased life expectancy has led to an increasing number of elderly people at risk of aging-related diseases. Aging is a complex molecular process that is influenced by genetic and environmental factors and cannot be avoided. Aging results in a progressive and deleterious changes that can increase the risk of dangerous ageassociated diseases like hypertension, cancer, chronic coronary disease, stroke, and diabetes, and neurodegenerative diseases, such as Alzheimer's. ${ }^{1-4}$

Some herbs have shown potential in reducing aging risk. Shen et $\mathrm{al}^{5}$ reviewed the efficacy of several medicinal Chinese plants against aging and its mechanisms. Some of them are related to telomeres and aging genes, such as SIRT. Telomeres are repetitive nucleotides with a TTAGGG sequence at the ends of chromosomes. Telomere length is shortened by 50-200 bp each time cell replication occurs, and this is related to limitations of somatic cell division, resulting in replicative
Tjandrawinata

Dexa Laboratories of Biomolecular

Sciences, Dexa Medica, Industri Selatan V

Block PP 7, Jababeka Industrial Estate II,

Cikarang, West Java 17550 , Indonesia

Tel +62-2I-898-4I-90I

Fax $+62-21-89841905$

Email raymond@dexa-medica.com 
senescence. ${ }^{6-9}$ SIRT is involved in gene repair, the cell cycle, metabolism, and oxidative stress through deacetylation of histones and nonhistone proteins. ${ }^{10,11}$

DLBS1649 is an extract from Centella asiatica, a common traditional herb in Indonesia. DLBS1649 was developed by Dexa Laboratories of Biomolecular Sciences (DLBS), Dexa Medica, an Indonesian pharmaceutical company exploring various natural compounds for medicinal applications. ${ }^{12-16}$ The herb belongs to the Apiaceae or Umbelliferae family. It is also commonly found in Malaysia, India, and parts of China. Some local names for this plant are pegaga in Malaysia and mandookapami in India. ${ }^{17} \mathrm{C}$. asiatica is commonly used as a traditional medicine in Malaysia and several other Asian countries. $^{18}$ Apart from being a traditional medicine, $C$. asiatica is also consumed as a salad and used in drinks. ${ }^{19}$ C. asiatica has been found to have such benefits as wound healing, ${ }^{20-23}$ improving memory, ${ }^{24,25}$ and antidepression ${ }^{26}$ and antidiabetic properties. ${ }^{27}$

In our study, to understand the complexities of aging, Drosophila melanogaster was used for preliminary study. Drosophila is a genus of small flies that belongs to the family Drosophilidae. ${ }^{28}$ D. melanogaster, commonly called the fruit fly, is about $3 \mathrm{~mm}$ in length. This type of fly is commonly used in research for several reasons, eg, short life cycle and life span, high fecundity, requires only a small cage, and relatively easy dietary requirements. ${ }^{29,30}$ These flies have also been studied for their telomeres. Research has suggested that D. melanogaster telomere mechanisms are different from other eukaryotes. Telomeres that are too long in D. melanogaster can affect its fecundity and fertility. ${ }^{31-33}$

The potential therapeutic efficacy of DLBS1649 was investigated by looking at its antiaging effects on telomere length and aging-associated genes, such as SIRT and $K L$, in an HEK293 cell-culture model. Research on calorie restriction was also carried out in vitro using 3T3L1 cells by analyzing the effect of DLBS1649 on fat-droplet formation. An in vivo study using D. melanogaster was also conducted to see DLBS1649's effect on survival enhancement.

\section{Methods}

\section{Preparations of DLBS 1649}

DLBS1649 was extracted from $C$. asiatica samples from Wonosobo, Central Java, Indonesia. The biological identity of $C$. asiatica was determined by the Herbarium Bogoriense, Research Center of Biology, Indonesian
Institute of Sciences (certificate1107/IPH.1.01/If.07/V/ 2019). C. asiatica herbs were macerated in 90\% (v:v) ethanol at a ratio of $1: 10 \mathrm{w}: \mathrm{v}$ herbal material:solvent at room temperature for 2 hours, followed by filtration. The filtrate was concentrated under low pressure at $60^{\circ} \mathrm{C}$ using a rotary evaporator (Büchi, Flawil, Switzerland). The concentrated extract was dried using a conventional oven at $70^{\circ} \mathrm{C}$ for $24-48$ hours to obtain a dry extract with $3 \%$ yield and then stored in a well-closed container at room temperature (not more than $30^{\circ} \mathrm{C}$ ).

Chemical identification of DLBS1649 was conducted using a thin-layer chromatography plate and silica gel 60 RP-18 $F_{254}$ with methanol:water at 7:3 v:v as eluent (Merck, Darmstadt, Germany). Asiaticoside and madecassoside were observed as marker compounds under UV $366 \mathrm{~nm}$ light and visible light after derivatization using 10\% v:v $\mathrm{H}_{2} \mathrm{SO}_{4}$ (Camag, Muttenz, Switzerland), which showed two brown bands at $R_{f} 0.41$ for asiaticoside and $R_{f} 0.49$ for madecassoside (Figure 1). The asiaticoside and madecassoside were quantified using high-pressure liquid chromatography (Waters) with an evaporative light-scattering detector. A $\mathrm{C}_{18}(4.6 \times 250 \mathrm{~mm}, 5 \mu \mathrm{m})$ column (Merck) was used for the stationary phase and acetonitrile and $0.1 \% \mathrm{v}: \mathrm{v}$ formic acid in water for the mobile phase. DLBS1649 contains $0.83 \%$ of asiaticoside and $0.99 \%$ of madecassoside.

\section{Cell Culture and Treatment of DLBSI649}

The human kidney cell line HEK293 (ATCC CL1573) and mouse adipocyte cell line 3T3L1 (ATCC CL173) were purchased from the American Type Culture Collection (Rockville, MD, USA). KL (aging-related gene) is expressed at particularly high levels in the kidney, ${ }^{34}$ and 3T3L1 is commonly used in fat or calorie studies. ${ }^{35}$ HEK293 cells were grown in MEM (Gibco), supplemented with 10\% FBS (Gibco), and 3T3L1 cells were grown in DMEM (Gibco) supplemented with 10\% FBS (Gibco). Both media were supplemented with $100 \mu \mathrm{g} / \mathrm{mL}$ penicillin-streptomycin (Gibco) and $1 \mathrm{mM}$ sodium pyruvate (Gibco). Both cell lines were incubated at $37^{\circ} \mathrm{C} 5 \% \mathrm{CO}_{2}$ until cultures had reached $80 \%$ confluence. HEK293 cells were divided into four groups: control (grown in standard medium), $0.5 \mathrm{mg} / \mathrm{mL}$ resveratrol (Naturalin, Hunan, China), $25 \mu \mathrm{g} / \mathrm{mL}$ DLBS1649, and $50 \mu \mathrm{g} / \mathrm{mL}$ DLBS1649 (treatment continuously added to the media). Later, RNA, DNA, and protein of HEK293 cells were isolated using Trizol reagents and lysis buffer. RNA was reverse-transcribed and used as a PCR template for gene amplification, while DNA and protein were used for absolute telomere 

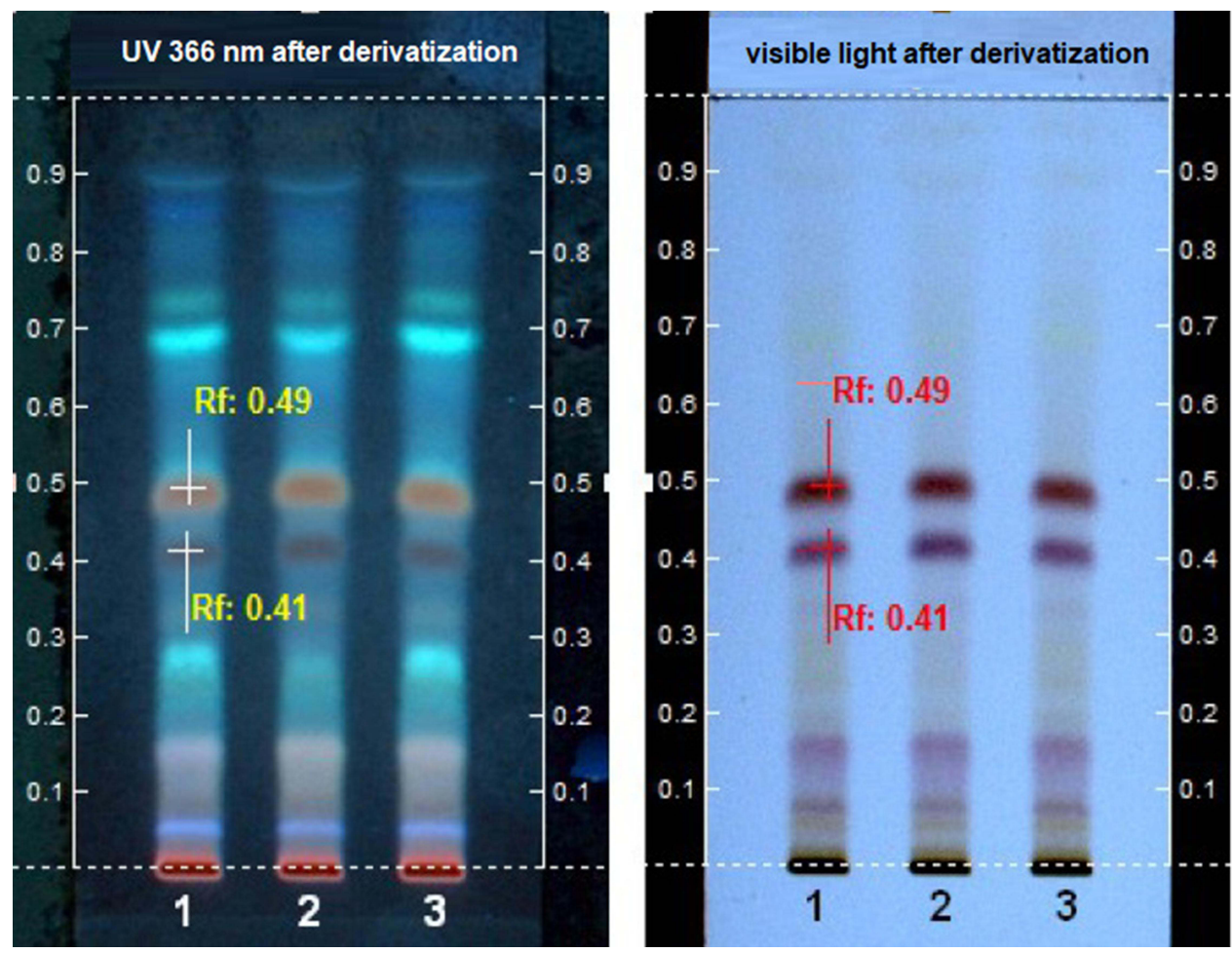

Figure I Thin-layer chromatography of DLBSI 649 under UV $366 \mathrm{~nm}$ and visible light.

length and telomerase quantification. As for 3T3L1, it was differentiated into adipocyte cells to be used for calorierestriction examination.

\section{Telomere-Length Assays}

Telomere-length calculation and primer pairs for telomeres or 36B4 used in quantitative real-time amplification were prepared as described by O'Callaghan et $\mathrm{al}^{36}$ and Cawthon et al. ${ }^{37}$ Briefly, a standard curve was established by dilution of known quantities of a synthesized 84-mer oligonucleotide telomere containing only TTAGGG repeats with $y$-axis as cycle threshold $\left(\mathrm{C}_{\mathrm{T}}\right)$ and $x$-axis as $\log \mathrm{TL}(\mathrm{kb})$. The $\mathrm{kb} /$ reaction value was then used to calculate telomere length in kilobits per human diploid genome. The number of diploid genomes was calculated using the $36 \mathrm{~B} 4$ product. A standard curve of 36B4 product was also established by dilution of known quantities of $36 \mathrm{~B} 4$ copies with $y$-axis as $\mathrm{C}_{\mathrm{T}}$ and $x$-axis as $\log 36 \mathrm{~B} 4$ copies. The telomere $\mathrm{kb} /$ reaction value was divided by the diploid genome copy number to give a total telomeric length per human diploid genome.

$$
\text { Total telomere length }=\frac{\log [(\text { TLkb })]}{\log [36 \mathrm{~B} 4 \text { copies }]}
$$

DNA from samples (control and DLBS1649-treated HEK293 cells) were used as templates for real-time assays to obtain $\mathrm{C}_{\mathrm{T}}$ and further converted using their standardcurve equation. DNA isolation was done using Trizol (Promega, Fitchburg, WI, USA). Telomere-sequence amplification was carried out using SsoFast EvaGreen Supermix (Bio-Rad, Hercules, CA, USA) and performed in Mini Opticon MJ Mini (Bio-Rad).

\section{Telomerase Quantification}

Total protein was isolated using RIPA buffer $(50 \mathrm{mM}$ Tris pH 8, $150 \mathrm{mM} \mathrm{NaCl}$, 0.5\% SDS, 1\% NP-40, 2 mM EDTA, and protease inhibitor) and measured using the Lowry method. Telomerase protein expression was observed using ELISA kit (Cusabio, Wuhan, China). All experiments were done according to manufacturer protocols.

\section{RNA Analysis}

Total RNA was obtained from cell culture using Trizol. The concentration of total RNA was measured using a NanoDrop 2000c spectrophotometer (Thermo Scientific, Waltham, MA, USA). cDNA amplification from total RNA (1 $\mu \mathrm{g})$ was done using GoScript reagent (Promega). Gene expression was observed using genespecific primers (Table 1). Gene amplification was conducted using GoTaq (Promega) and performed using a T3000 Thermocycler (Biometra, Göttingen, Germany). 
Table I Primer sequences

\begin{tabular}{|l|l|}
\hline & \multicolumn{1}{c|}{ Sequences } \\
\hline Telomere & $\begin{array}{l}\text { Forward: 5'-CGGTTTGTTTGGTGGGTTTGGGTTTGGGTTTGGGTT-3' } \\
\text { Reverse: 5'-GGCTTGCCTTACCCTTACCCTTACCCTTACCCTTACCCT-3' }\end{array}$ \\
\hline $\mathbf{3 6 B 4}$ & $\begin{array}{l}\text { Forward: 5'-CAGCAAGTGGGAAGGTGTAATCC-3' } \\
\text { Reverse: 5'- CCCATTCTATCATCAACGGGTACAA-3 }\end{array}$ \\
\hline TERT & $\begin{array}{l}\text { Forward: 5'-CGTGGTTTCTGTGTGGTGTC-3' } \\
\text { Reverse: 5'-CTTGTCGCCTGAGGAGTAG-3' }\end{array}$ \\
\hline SIRTI & $\begin{array}{l}\text { Forward: 5'-AGTGCAGCAGCAGTTGCTAA-3' } \\
\text { Reverse: 5'-TTTCAATTCTTGCATCTCC-3' }\end{array}$ \\
\hline SIRT2 & $\begin{array}{l}\text { Forward: 5'-GAGGCCAGGACAACAGAGAG-3' } \\
\text { Reverse: 5'-TAGAGATTTGCTGGGGTTGG-3' }\end{array}$ \\
\hline CMYC & $\begin{array}{l}\text { Forward: 5'-CTGGCAAAAGGTCAGAGTCTGGATGACCTT-3' } \\
\text { Reverse: 5'-TGTCTCAGGACTCTGACACTGTCCAACTTG-3' }\end{array}$ \\
\hline KL & $\begin{array}{l}\text { Forward: 5'-AGCTACAACAACGTCTTCCG-3' } \\
\text { Reverse: 5'-GGGTTGTCGATGGTGATCCA-3' }\end{array}$ \\
\hline TP53 & $\begin{array}{l}\text { Forward: 5'-TAACAGTTCCTGCATGGGCG-3' } \\
\text { Reverse: 5'-AGGACAGGCACAAACACGCAC-3' }\end{array}$ \\
\hline
\end{tabular}

Images were captured using Chemi-Doc (Bio-Rad). Relative levels of target-gene mRNA expression were normalized to the internal control.

\section{Adipogenic Differentiation}

The cells were placed in six-well plates and differentiated using differentiation medium (growing media with addition of $0.5 \mathrm{mM} 3$-isobutyl-1-methylxanthine, $1 \mathrm{mM}$ dexamethasone, and $20 \mu \mathrm{g} / \mathrm{mL}$ insulin [Sigma-Aldrich) for 48 hours. Subsequently, the differentiation medium was replaced with culture medium supplemented with $20 \mu \mathrm{g} /$ $\mathrm{mL}$ insulin and treated with $0.5 \mathrm{mg} / \mathrm{mL}$ resveratrol and various doses of DLBS1649 $(10,25,50$, and $100 \mu \mathrm{g} / \mathrm{mL})$ for the next 12 days. Since adipocyte differentiation can be determined using oi red $\mathrm{O}$ (ORO) staining, this was used to measure fat-droplet formation in 3T3L1 cells.

\section{Oil Red O Fat-Droplet Assay}

Fat-droplet quantity within adipose cells was measured using an ORO assay. Differentiated adipose 3T3L1 cells were stained with ORO dye (Sigma-Aldrich). The dye was diluted with double-distilled $\mathrm{H}_{2} \mathrm{O}$ at 3:2, mixed, and incubated at room temperature for 20 minutes. After incubation, ORO was filtered with a $0.2 \mu \mathrm{m}$ filter membrane. Formalin 10\% reagent in PBS (Sigma-Aldrich) was used to fixate the cells for 1 hour, which were subsequently washed with 60\% isopropanol (Sigma-Aldrich). ORO application was carried out for 10 minutes. Cells were then washed using double-distilled $\mathrm{H}_{2} \mathrm{O}$ and allowed to dry at room temperature. ORO retention extracted using $60 \%$ isopropanol for 10 minutes and quantified using spectrophotometry at $520 \mathrm{~nm}$.

\section{D. melanogaster and Culture Conditions}

The fruit flies were purchased from the Bandung Institute of Technology. Cornstarch, sugar, agar, and yeast were purchased from a local store. Methylparaben was purchased from Sigma-Aldrich. Riboflavin was obtained from DSM Nutritional Products (Baden-Württemberg, German). The fruit flies were kept in $300 \mathrm{~mL}$ glass jars. Each jar contained $5 \mathrm{~mL}$ culture medium. The basal culture medium comprised $72 \mathrm{~g}$ cornmeal, $72 \mathrm{~g}$ glucose, $10 \mathrm{~g}$ yeast, $6 \mathrm{~g}$ agar, $40 \mathrm{~mL}$ antiseptic, and water to prepare $500 \mathrm{~mL}$ medium. ${ }^{38}$ The mixture was cooked and poured into vials. Jars were kept at room temperature on an 8hour-16 hour light-dark cycle.

\section{Survival Assays of $D$. melanogaster}

Male and female D. melanogaster were divided into two groups: control and treatment. The control group were fed basal culture medium. The treatment group were fed culture medium supplemented with DLBS1649 at final 
concentration 2 or $20 \mathrm{mg} / \mathrm{mL}$ and riboflavin at final concentration $120 \mu \mathrm{g} / \mathrm{mL}$. Numbers of dead flies were recorded daily until no survivor remained. Survival graphs illustrating the survival rate of D. melanogaster for a certain period were constructed as described by Altman: ${ }^{39}$

$$
\text { Survival rate }=1-\frac{\mathrm{d}}{n}
$$

where $d$ is the number dying between $t_{1}$ and $t_{2}$, and $n$ the remaining population number that could have failed in the interval. Restricted mean survival time (RMST) method was used for comparisons between treatments. RMST is one of the methods that can be used when a hazard ratio is violated (crossed curves on a Kaplan-Meier plot), and calculates MST on follow-up. ${ }^{40}$

\section{Statistical Analysis}

Statistical differences between the test and control groups were determined by $t$-tests using QuickCalcs (GraphPad Software. Values are expressed as means \pm SD for a minimum of three experiments. Comparison of survivorship of D. melanogaster data was calculated by RMST tests using the EZR statistical software by Yoshinobu Kanda (http://www.jichi.ac.jp/saitama-sct) and the survRM2 package by Uno et al ${ }^{40}$ (R Foundation, Vienna, Austria). $p<0.05$ was considered statistically significant.

\section{Results}

\section{DLBS 649 Maintained Absolute Telomere Length}

To assess telomere length, we used telomere samples from cell passages 13, 23, 33, and 43. Standard curves for telomeres and 36B4 were generated from a single copy gene that was used as a control for amplification and checked the results' reliability. The equation and regression values of telomeres and 36B4 were $-3.509 x+47.984$ $\left(R^{2}=0.9939\right)$ and $-3.737 x+35.269\left(R^{2}=0.9929\right)$, respectively (Figure $2 \mathrm{~A}$ ). The high $\mathrm{R}^{2}$ standard-curve values for telomeres and 36B4 $(>0.99)$ indicated that the procedure was significantly convincing to measure absolute telomere lengths of the samples. DNA of control and treated HEK293 cells of five replicates were evaluated for absolute telomere length using real-time PCR. In the control
A

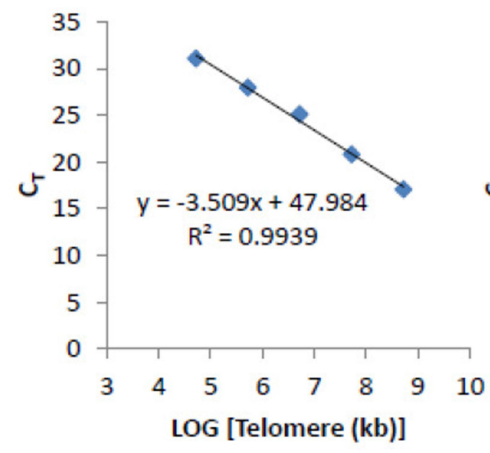

B

B
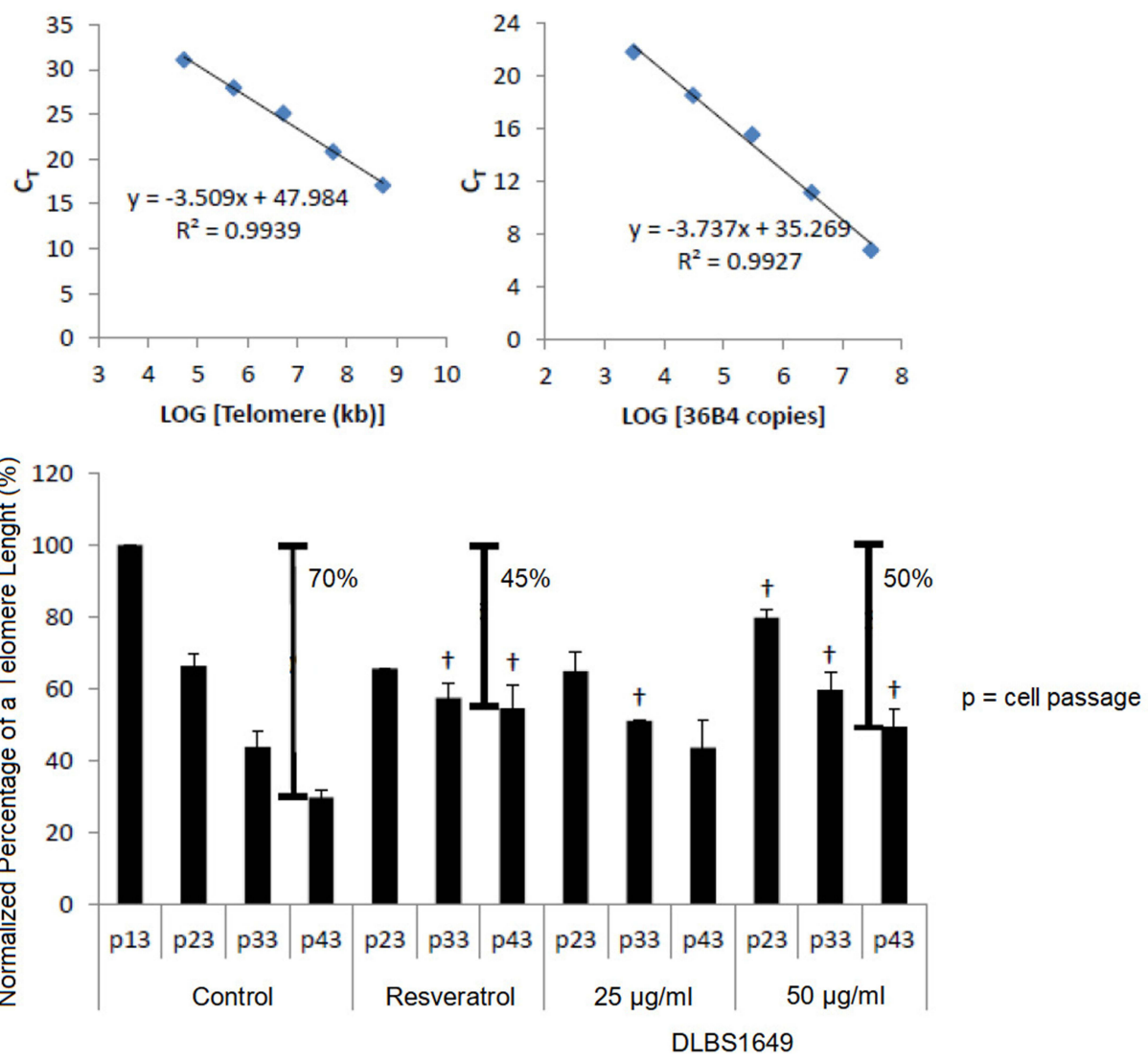

Figure 2 Effect of DLBSI649 $(25 \mu \mathrm{g} / \mathrm{mL}$ and $50 \mu \mathrm{g} / \mathrm{mL})$ on telomere length. (A) Standard curves for telomere and 36B4 generated from $R^{2}: 0.993$ and 0.993 , respectively. (B) Posttreatment telomere length from cell passages 13, 23, 33, and 43. Decreased telomere lengths at passage 43 are indicated. ${ }^{\dagger} p<0.05$. 
group, length decreased with age (cell passage 43) up to $70 \%$ compared to cell passage 13 , while continuous supplementation of resveratrol and DLBS1649 repressed telomere shortening by $45 \%$ and $50 \%$ respectively, in cell passage 43 compared to cell passage 13 (Figure 2B).

\section{DLBSI649 Prevented Decreases in Telomerase Protein Levels and TERT Expression}

The effect of continuous supplementation of $0.5 \mathrm{mg} / \mathrm{mL}$ resveratrol and two doses of DLBS1649 (25 and 50 $\mu \mathrm{g}$ / $\mathrm{mL}$ ) for 15 weeks on telomerase protein expression in HEK293-cell passages 13-43 (cells were subcultured every 2 or 3 days to increase passage numbers, cells were harvested every 10 passages, and RNA and protein were isolated) was observed. Samples from passages 13 and 23 were used. Atandard curve for telomerase was generated with equation and regression values of $0.0987 x$ $+0.021\left(R^{2}=0.992\right.$, Figure $\left.3 \mathrm{~A}\right)$. The result showed that telomerase expression decreased by $46 \%$ during aging. Resveratrol and DLBS1649 repressed the decrease by
$26 \%$ and $28 \%$, respectively. The effect of DLBS1649 in repressing the decrease in telomerase protein expression was also found to be dose-dependent (Figure 3B).

The effect of DLBS1649 on the telomerase catalytic subunit TERT was also evaluated at the mRNA level. The result showed that TERT mRNA expression decreased by 56\% with aging (control group). Resveratrol, DLBS1649 $25 \mu \mathrm{g} / \mathrm{mL}$, and DLBS1649 $50 \mu \mathrm{g} / \mathrm{mL}$ blocked the decrease by $50 \%, 55 \%$, and $29 \%$, respectively. The effect of DLBS1649 in repressing telomerase RNA expression was also found to be dose-dependent (Figure 4).

\section{DLBSI 649 Enhanced Expression of Genes Involved in Cell Cycle}

SIRT1, SIRT2, CMYC, and KL expression decreased during aging $(56 \%, 44 \%, 40 \%$, and $46 \%$, respectively; Figure 5). Also, continuous supplementation of DLBS1649 $25 \mu \mathrm{g} / \mathrm{mL}$ repressed the decrease in SIRT1, SIRT2, CMYC, and KL expression during aging (35\%, $42 \%, 27 \%$, and $37.5 \%$, respectively), while DLBS 1649 $50 \mu \mathrm{g} / \mathrm{mL}$ repressed these by $18 \%, 25 \%, 9 \%$, and $30 \%$,
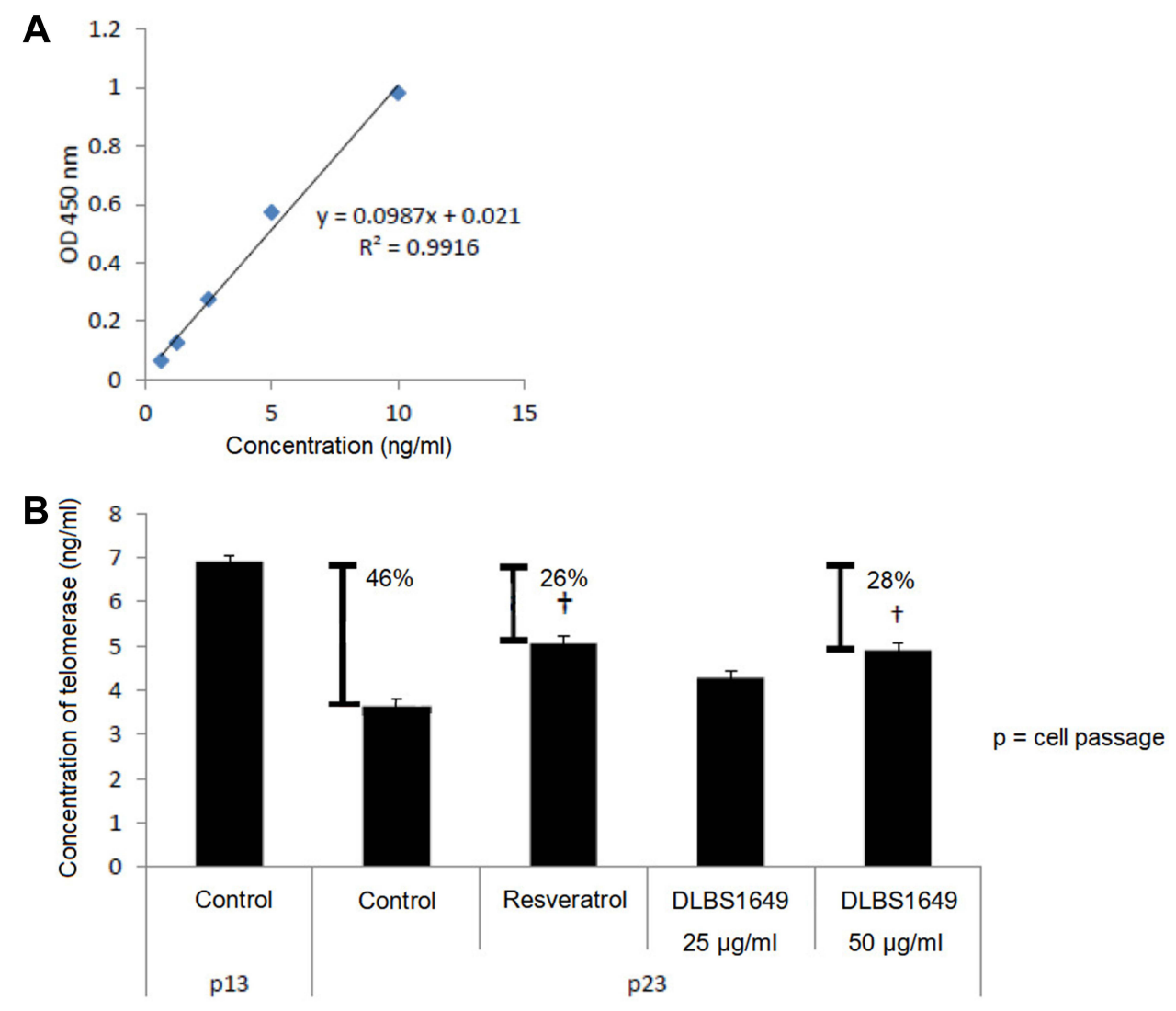

Figure 3 Effect of DLBSI649 on telomerase levels during aging. (A) Standard curve of telomerase quantification with $R^{2}=0.992$. (B) Concentration of telomerase following several treatments on cell passages 13 and $23 .{ }^{\dagger} p<0.05$. 


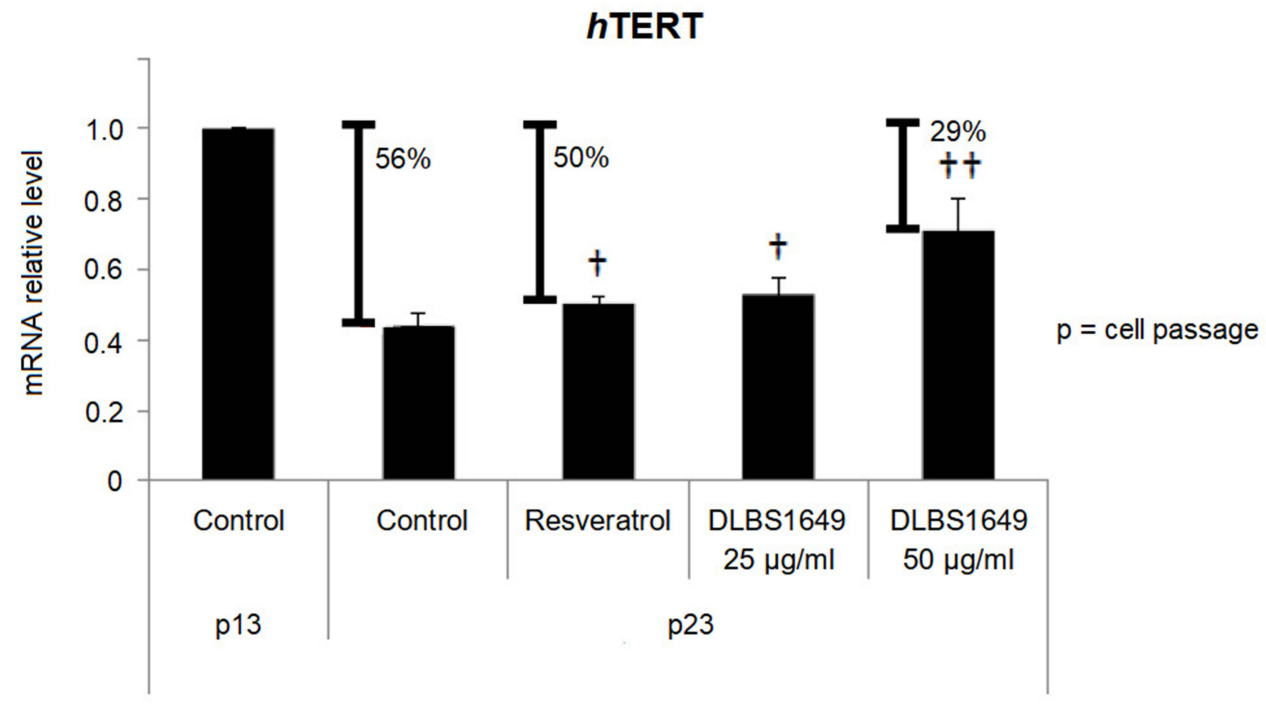

Figure 4 Posttreatment mRNA hTERT after from cell passages I 3 and 23 . HEK293 cells were continuously treated with DLBSI649 $50 \mu g / \mathrm{mL}$ and resveratrol I $20 \mu g / \mathrm{mL}$. ${ }^{\dagger} p<0.05 ;{ }^{\dagger \dagger} p<0.01$.

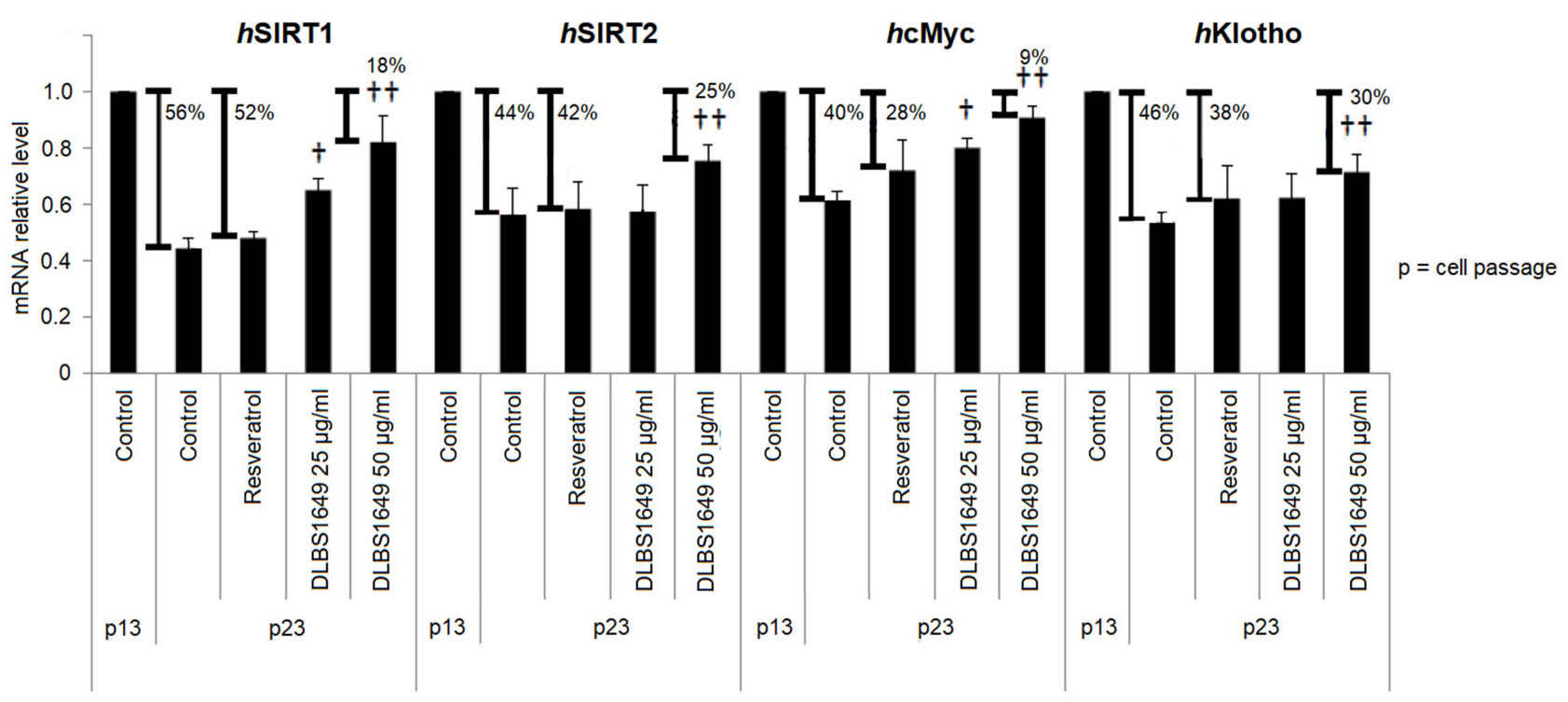

Figure 5 Gene expression (mRNA) of HEK293 cells at passages I3 and 23 in the presence of DLBSI649 and resveratol (as positive control). Genes analyzed were SIRTI, SIRT2, CMYC, and KL. ${ }^{\dagger} p<0.05 ;{ }^{\dagger \dagger} p<0.01$.

respectively. Higher DLBS1649 concentration had a more significant effect. The most significant effect of DLBS1649 was on CMYC expression, which indicated that DLBS1649-induced antiaging activity was primarily through stabilizing CMYC expression. However, a significant effect for resveratrol was found only on TERT expression. This was concluded from three independent replicates in HEK293 passages 13-23.

Tumorigenic activity of DLBS1649 was also observed. Since the cell-cycle profiles of antiaging and tumor progression are very similar, and both increased the cell cycle, further determining cell proliferation. The effect of BAF on TP53 gene expression was also evaluated. DLBS1649 did not significantly affect the TP53 mRNA expression (Figure 6), implying that DLBS1649 is not a tumorigenic agent.

\section{DLBS 1649 Decreased Fat Droplets}

Calorie restriction was evaluated by observing fat-droplet accumulation in adipogenesis differentiation. Three concentrations of DLBS1649 $(25,50$, and $100 \mu \mathrm{g} / \mathrm{mL})$ and resveratrol were administered to 3T3L1 cells continuously 


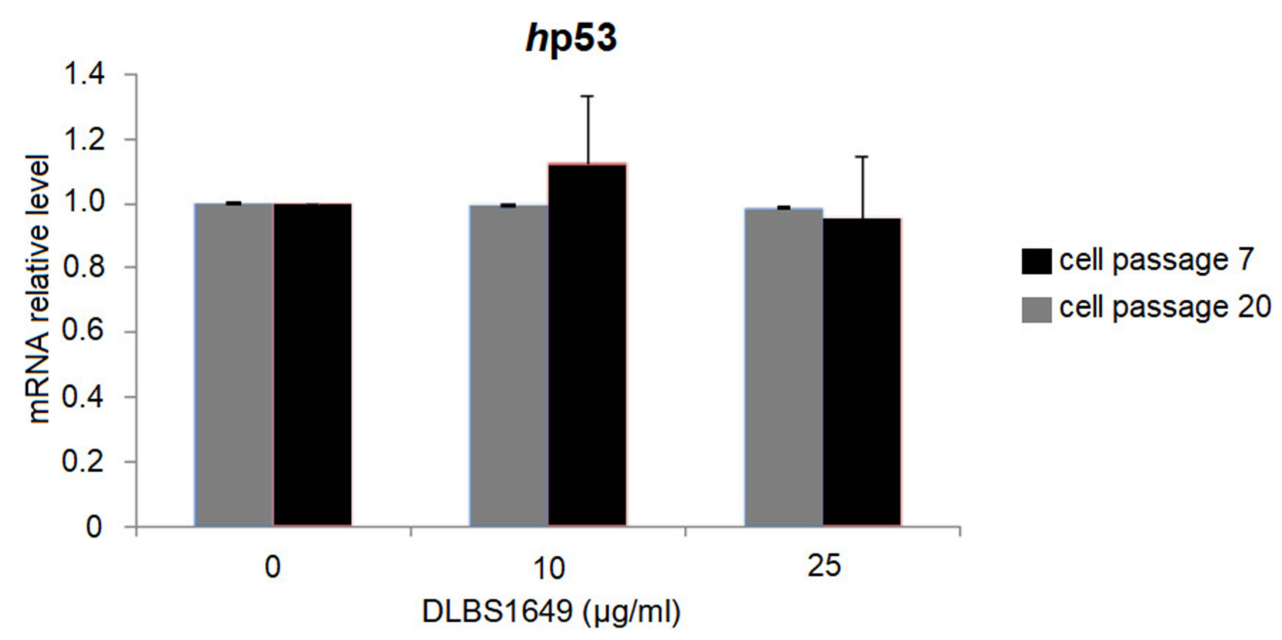

Figure 6 TP53 mRNA level following continuous administration of DLBSI649ler cell passages 7 and 20.

from day 3 to day 14 in adipogenesis differentiation. ORO staining showed that fat droplets in resveratrol treatment were $28 \%$ less than the control, while DLBS1649 (50 and $100 \mu \mathrm{g} / \mathrm{mL}$ ) were almost identical $-37 \%$ less than the control (Figure 7). Fewer fat droplets with resveratrol and DLBS1649 treatment likely indicated calorie restriction.

\section{DLBSI649 Increased Survival of $D$. melanogaster}

The control samples of male and female flies showed different survival rates: male $D$. melanogaster had longer survival than the female ones, with significantly lower RSMT of the females than the males $(33.36 \%$ lower, $p<0.001$; Table 2, Figure 8).

DLBS1649 administration increased survival in both male and female $D$. melanogaster. Two doses of DLBS1649 were used in this study $(2 \mathrm{mg} / \mathrm{mL}$ and 20

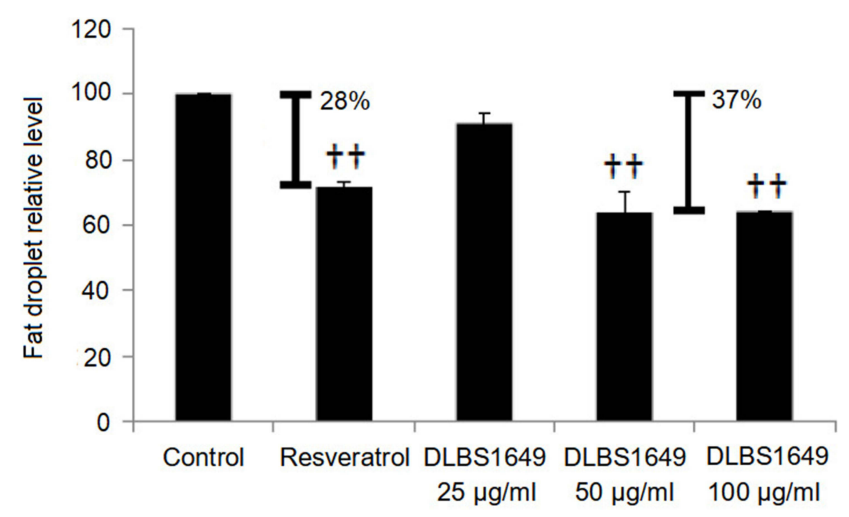

Figure 7 Fat droplets in 3T3LI adipocyte cells following treatment with DLBSI649 and resveratrol. Resveratrol $120 \mu \mathrm{g} / \mathrm{mL}$ and DLBSI6490 25, 50, and $100 \mu \mathrm{g} / \mathrm{mL}$ were given to the $3 \mathrm{~T} 3 \mathrm{LI}$ cells on day 3 to 14 incubation. $\mathrm{mg} / \mathrm{mL}$ ). Riboflavin $120 \mu \mathrm{g} / \mathrm{mL}$ was used as a positive control. The time frame used in this study was 80 days, except for control females and DLB1649 $20 \mathrm{mg} / \mathrm{mL}$ comparison60 days), because the females receiving DLBS1649 $20 \mathrm{mg} / \mathrm{mL}$ treatment did not survive 80 days. Administration of $2 \mathrm{mg} / \mathrm{mL}$ DLBS1649 in males increased RMST by $12.58 \%(p=0.074)$ compared to controls. Higher DLBS1649 administration $(20 \mathrm{mg} / \mathrm{mL})$ resulted in similar RSMT to control males (increased by $0.86 \%, p=0.9$ ). Treatment with riboflavin $120 \mu \mathrm{g} / \mathrm{mL}$ decreased RMST by $3.69 \%$ ( $p=0.6)$ compared to control males. This showed that DLBS1649 and riboflavin administration did not provide significant benefit in male $D$. melanogaster survival (Table 2, Figure 9).

Observation of female D. melanogaster RMST showed that DLBS1649 $2 \mathrm{mg} / \mathrm{mL}$ administration significantly increased RMST by $23.87 \%(p=0.001)$ compared to controls. The higher dose of DLBS1649 $(20 \mathrm{mg} / \mathrm{mL})$ also significantly increased RMST by $15.62 \%(p=0.019)$ compared to control females, but RSMT was lower than that with DLBS649 $2 \mathrm{mg} / \mathrm{mL}$ treatment. Riboflavin administration increased RMST by $14.36 \%(p=0.082)$ compared to control females. DLBS1649 administration appeared to have more of an effect on female $D$. melanogaster. The results also suggested that DLBS1649 $2 \mathrm{mg} / \mathrm{mL}$ was better than $20 \mathrm{mg} / \mathrm{mL}$ in female D. melanogaster. DLBS1649's effect on survival was also better than riboflavin $120 \mu \mathrm{g} /$ $\mathrm{mL}$ (Table 2, Figure 10).

Regarding the effect of DLBS1649 on D. melanogaster mortality rates (Figure 11), male and female rates were lower than controls for both the $2 \mathrm{mg} / \mathrm{mL}$ and $20 \mathrm{mg} / \mathrm{mL}$ samples. Differences in mortality rates were seen at days 
Table 2 RMST of Drosophila melanogaster

\begin{tabular}{|c|c|c|c|c|c|}
\hline & RSMT (days) & Increment (\%) & Days & $\mathbf{n}$ & $p$ \\
\hline Control male & 52.37 & & 80 & 86 & \\
\hline Control female & 34.90 & -33.36 & & 115 & $<0.001 *$ \\
\hline Control male & 52.37 & & 80 & 86 & \\
\hline DLBSI 649 (2 mg/mL), male & 58.96 & 12.58 & & 105 & 0.074 \\
\hline Control male & 52.37 & & 80 & 86 & \\
\hline DLBS I 649 (20 mg/mL), male & 52.82 & 0.86 & & 95 & 0.9 \\
\hline Control male & 52.37 & & 80 & 86 & \\
\hline Riboflavin ( $120 \mu \mathrm{g} / \mathrm{mL})$, male & 50.44 & -3.69 & & 99 & 0.598 \\
\hline Control female & 34.90 & & 80 & 115 & \\
\hline DLBSI 649 (2 mg/mL), female & 43.23 & 23.87 & & 158 & $0.00 I^{*}$ \\
\hline Control female & 33.03 & & 60 & 115 & \\
\hline DLBS I 649 (20 mg/mL), female & 38.19 & 15.62 & & 198 & $0.019 *$ \\
\hline Control female & 34.90 & & 80 & 115 & \\
\hline Riboflavin ( $120 \mu \mathrm{g} / \mathrm{mL}$ ), emale & 39.91 & 14.36 & & 147 & 0.082 \\
\hline
\end{tabular}

Note: ${ }^{*} p<0.05$.

Abbreviation: RSMT, restricted mean survival time.

$20(11.03 \% 17.75 \% 2 \mathrm{mg} / \mathrm{mL}$ and $20 \mathrm{mg} / \mathrm{mL}$, respectively) and $50(38.40 \% 51.88 \% 2 \mathrm{mg} / \mathrm{mL}$ and $20 \mathrm{mg} / \mathrm{mL}$, respectively) compared to controls (day $2021.39 \%$, day 50 $64.18 \%$ ). In the middle of the observation time frame (days 30, 40, and 50), D. melanogaster treated with 2 $\mathrm{mg} / \mathrm{mL}$ showed $55.24 \%, 21.16 \%$, and $40.16 \%$ less mortality than controls, respectively, while treatment with $20 \mathrm{mg} /$ $\mathrm{mL}$ showed $18.66 \%, 11.90 \%$, and $19.17 \%$ less than controls, respectively.

In sex-related observations, mortality rates for male $D$. melanogaster receiving $2 \mathrm{mg} / \mathrm{mL}$ and $20 \mathrm{mg} / \mathrm{mL}$ DLBS1649 were lower at days 30 (18.10\% and 21.05\%, respectively) and 60 (30.48\% and $42.11 \%$, respectively) than controls (day $3024.42 \%$, day $6052.33 \%$ ) within the same time frame (10-80 days). For female $D$. melanogaster, administration of $2 \mathrm{mg} / \mathrm{mL}$ and $20 \mathrm{mg} / \mathrm{mL}$ DLBS1649 resulted in lower mortality rates at day 20 (7.59\% and $16.67 \%$, respectively) and day $50(46.20 \%$ and $63.13 \%$, respectively) than controls (day $2030.43 \%$, day $5075.65 \%$ ) within the same time frame (10-80 days).

Riboflavin (positive control) also lowered this parameter in male $D$. melanogaster compared with controls, but in a shorter time span, ie, day $30(20.20 \%)$ to day 50 (42.42\%), while DLBS1649 was observed until day 60 . Giving riboflavin to the females lowered the mortality rate compared with controls, but took longer: day 20 (27.21\%) to day $60(74.15 \%)$. The effect of DLBS1649 or riboflavin was more visible on females. Its effect on mortality was faster in females than males (day 20 versus day 30). The effect of riboflavin on female mortality was longer than with DLBS1649 (days 20-60). Mortality was observed in line with survival.

\section{Discussion}

C. asiatica has been studied extensively and found to have several benefits. Asiatic acid is one of the active components found in $C$. asiatica, and has reported to have potential in the treatment of various diseases. ${ }^{41-43}$ Another indicated the efficacy of $C$. asiatica as a neuroprotective agent. $^{44}$ Soumyanath et $\mathrm{al}^{45}$ reported on the use of $C$. asiatica substances for neurite elongation, and Tiwari et al46 found benefits from $C$. asiatica in neurodegenerative treatment. The use of $C$. asiatica for cosmetics also has been reported by Bylka et al. ${ }^{47}$ On the other hand, terpenoids in $C$. asiatica increasing collagen content was reported by James and Dubery. ${ }^{48}$ DLBS1649 has been identified to have two compounds in common with $C$. asiatica, namely asiaticoside and madecassoside. Both these have been observed to have anti-aging related activity in the cosmetic field. ${ }^{47,48}$

As mentioned before, a hallmark of aging is strictly associated with the length of telomeres. Research on $C$. asiatica in relation to the effect on telomeres and SIRT has shown promising results. Several plants have been reported to have antiaging activity related to telomere activity. Guo et $\mathrm{al}^{49}$ found that astragaloside and cycloastragenol in Astragalus membranaceus possessed antiaging effects on human embryonic lung fibroblasts that were related to telomere activity. Salvador et $\mathrm{al}^{50}$ reported that TA65, a substance extracted from an antiaging medicinal 


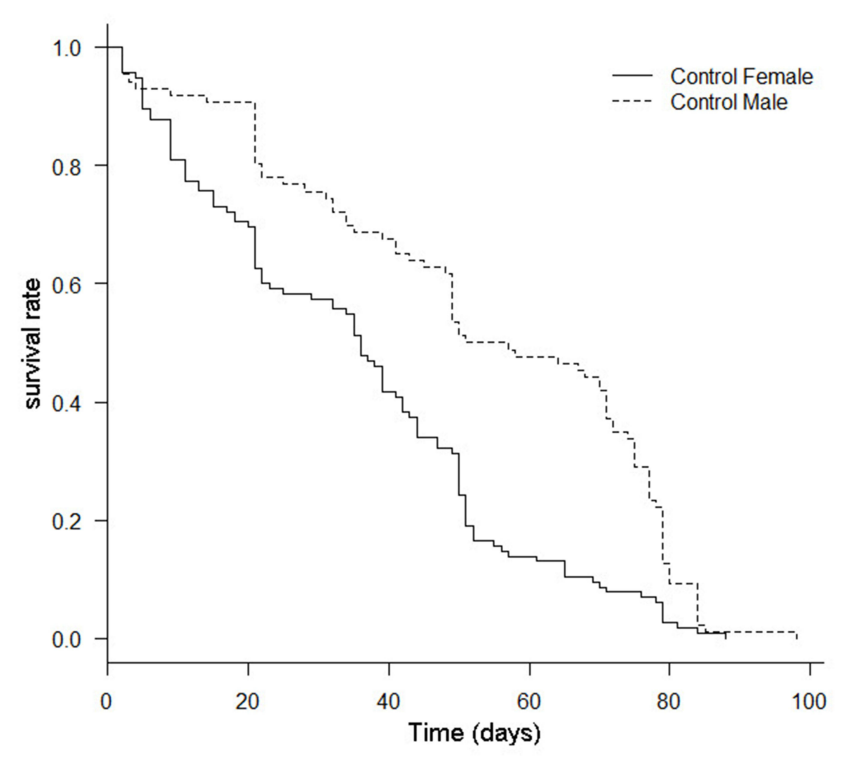

Figure 8 Survival profile of male and female Drosophila melanogaster incubated for 80 days.

Chinese plant, lengthened telomeres in a randomized, double blind, placebo-controlled study in human subjects aged 53-87 years. Guruprasad et $\mathrm{al}^{51}$ also reported that amalaki rasayana, a traditional Indian antiaging drug, maintained telomerase activity in human subjects aged 45-60 years. A bioactive extract of $C$. asiatica, DLBS1649 (25 and $50 \mu \mathrm{g} / \mathrm{mL}$ ), also showed an ability in this study to prevent telomere shortening and maintained telomerase activity.

Prevention of telomere shortening with DLBS1649 50 $\mu \mathrm{g} / \mathrm{mL}$ was found in this study, with less decrease in telomere length in treated samples $(50 \%)$ than controls (70\%) after 30 passages (p13-p43). DLBS1649 $50 \mu \mathrm{g} /$ $\mathrm{mL}$ maintained telomerase activity by lowering the decrease in TERT protein level in treated samples $(28 \%)$ compared to controls (46\%). This was in accordance with TERT expression, which also showed smaller decreases in DLBS1649 $50 \mu \mathrm{g} / \mathrm{mL}$-treated samples (29\%) than controls (56\%). Both results were seen after cells undergoing ten passages ( $13-\mathrm{p} 23)$, which suggested that reduction in telomere shortening was caused by maintaining telomerase activity. Also, CMYC is known to be one of the transcription factors of TERT. ${ }^{52}$ We found that $C M Y C$ expression had decreased after ten passages (p13-p23); however, addition of DLBS1649 $50 \mu \mathrm{g} / \mathrm{mL}$ seemed to decrease expression (9\%) less than controls (40\%).

Telomere shortening which results in cell senescence and limited cell division. Telomerase is enzyme that maintains telomere length and prevents aging. igh telomerase activity can also be Almost every cancer profile shows high telomerase activity. ${ }^{53}$ To observe whether DLBS1649 can initiate cancer, TP53 expression was investigated in young and passaged cells. p53 is a protein that regulates the cell cycle and hence functions as a tumor suppressor. Our results showed that DLBS1649 administration resulted in no significant difference in TP53 gene expression in young or older passaged cells. Telomere and telomerase investigation also showed that DLBS1649-treated cells had telomere shortening, which means the treated cells still underwent aging, but in a slower manner than the control cells. These results indicate that DLBS1649 has value in reducing aging effects without inducing cancerous traits in cells.

Antiaging research has reported on the involvement of sirtuin, a protein once identified as a genetic silencer. Sirtuin could be a therapeutic target for neurodegeneration and antiaging. ${ }^{54,55}$ Several studies on sirtuin in neurodegeneration applications have been carried out by Xu et $\mathrm{al}^{56}$ and Qian et $\mathrm{al}^{57}$ using C. asiatica. Their research showed that $C$. asiatica demonstrated neuroprotective benefits with several indication which was promoting SIRT1 level in mice. Research on $C$. asiatica effects on anti-aging involved sirtuin is scarce. Examples of antiaging studies using other plants have been Han et $\mathrm{al}^{58}$ on Ganoderma lucidum, Sung et $\mathrm{al}^{59}$ on Humulus japonicus, and Kou et $\mathrm{al}^{60}$ on Ampelopsis grossedentata. In this study, the antiaging effects of $C$. asiatica on sirtuin were assessed by observing SIRT1 and SIRT2 expressions. The results showed smaller decreases in SIRT1 and SIRT2 expression in the DLBS1649 $50 \mu \mathrm{g} / \mathrm{mL}$-treated samples $(18 \%$ and $25 \%$, respectively) than controls (56\% and $44 \%$, respectively). Sirtuin may indicate antiaging activity which implied in the cell cycle and energy metabolism. High expression of SIRT in Caenorhabditis elegans results in increases life span. ${ }^{19,61}$ DLBS1649 activity against the containment of SIRT1 and SIRT2 expression shows its potential as antiaging agent.

$\mathrm{KL}$ is a type 1 single-pass transmembrane glycoprotein located at the plasma membrane and Golgi apparatus. It is expressed at particularly high levels in the kidneys, and has been studied in relation to antiaging. Several studies on mice have shown that deficient $K L$ expression causes signs of aging, whereas overexpression increases life span. The antiaging activity of KL might be related to organ protection. ${ }^{34}$ Zhou et al ${ }^{62}$ studied KL antiaging activity in Polygonatum multiflorum. Plant extracts containing tetrahydroxystilbene glucoside were found to extend mouse 

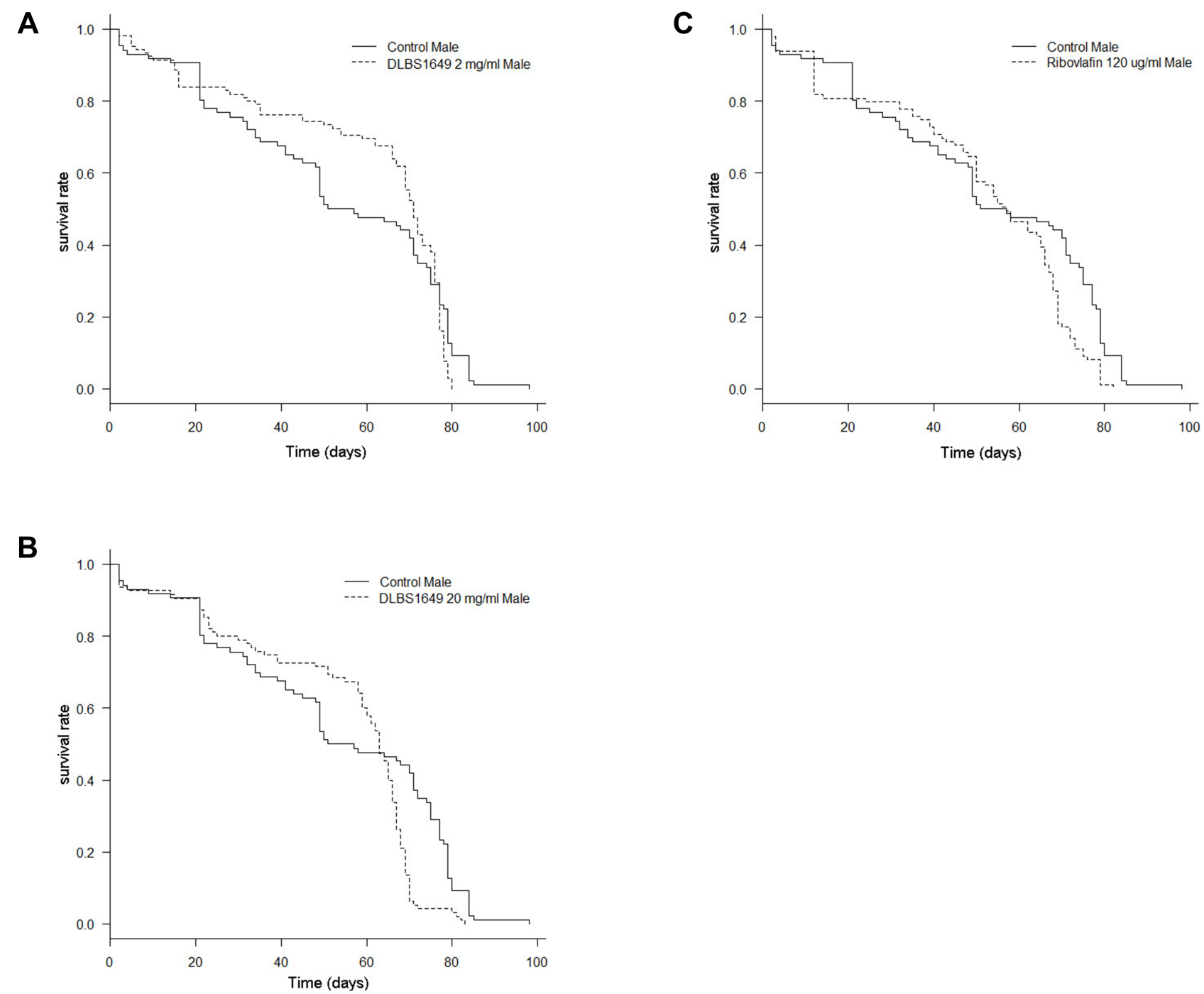

Figure 9 Effect of DLBSI649 and riboflavin on RMST of male Drosophila melanogaster. (A) Treatment with $2 \mu \mathrm{g} / \mathrm{mL}$ DLBSI649 (RMST increased by I2.58\% $p=0.076$ ] compared to controls. (B) Treatment with $20 \mu \mathrm{g} / \mathrm{mL}$ DLBSI 649 (RMST increased by $0.86 \%, p=0.9$ ). (C) Treatment with $120 \mu \mathrm{g} / \mathrm{mL}$ riboflavin (RMST decreased by by $3.69 \%$, $p=0.6$.

life span, characterized by increase in $K L$ expression. Our results showed that $K L$-expression decrease was lower in DLBS1649 $50 \mu \mathrm{g} / \mathrm{mL}$-treated samples (30\%) than controls $(46 \%)$ after ten passages (p13-p23). This indicates the potential of DLBS1649 as an antiaging agent via $K L$ expression.

Another factor that might be related to extended life span is calorie restriction, which is the limitation of calories that enter the body without malnutrition. This was also observed in this study. Calorie restriction exerts antiaging effects through such mechanisms as sncRNAs, diet composition, and IGF1 signaling. The relationship between calorie restriction and anti-aging has been well discussed by Liang et al, ${ }^{63}$ Al-Regaiey et al, ${ }^{64}$ LópezLluch et $\mathrm{al}^{65}$ and Blagosklonny. ${ }^{66}$ An example of a substance that provides calorie restriction is rapamycin. Some investigations have shown that rapamycin can inhibit formation of fat bodies ${ }^{67,68}$ and prolong life span in mice. ${ }^{69-71}$ In this study, DLBS1649's effect on calorie restriction was checked via fat-droplet formation in 3T3L1 cells, and $50 \mu \mathrm{g} / \mathrm{mL}$-treated samples showed less fat $(37 \%$ lower than controls). This suggests that DLBS1649 might play a calorie-restriction role that leads to adipogenic metabolism change. Several studies onantiaging and fat metabolism have been carried out in rat and mouse adipocyte tissue. Miller et $\mathrm{al}^{72}$ showed that calorie restriction can prevent metabolic changes in adipocyte tissue caused by aging. Kim et $\mathrm{al}^{73}$ also showed that calorie restriction can prevent change in ectopic fat distribution caused by aging that lead to fat accumulation in 

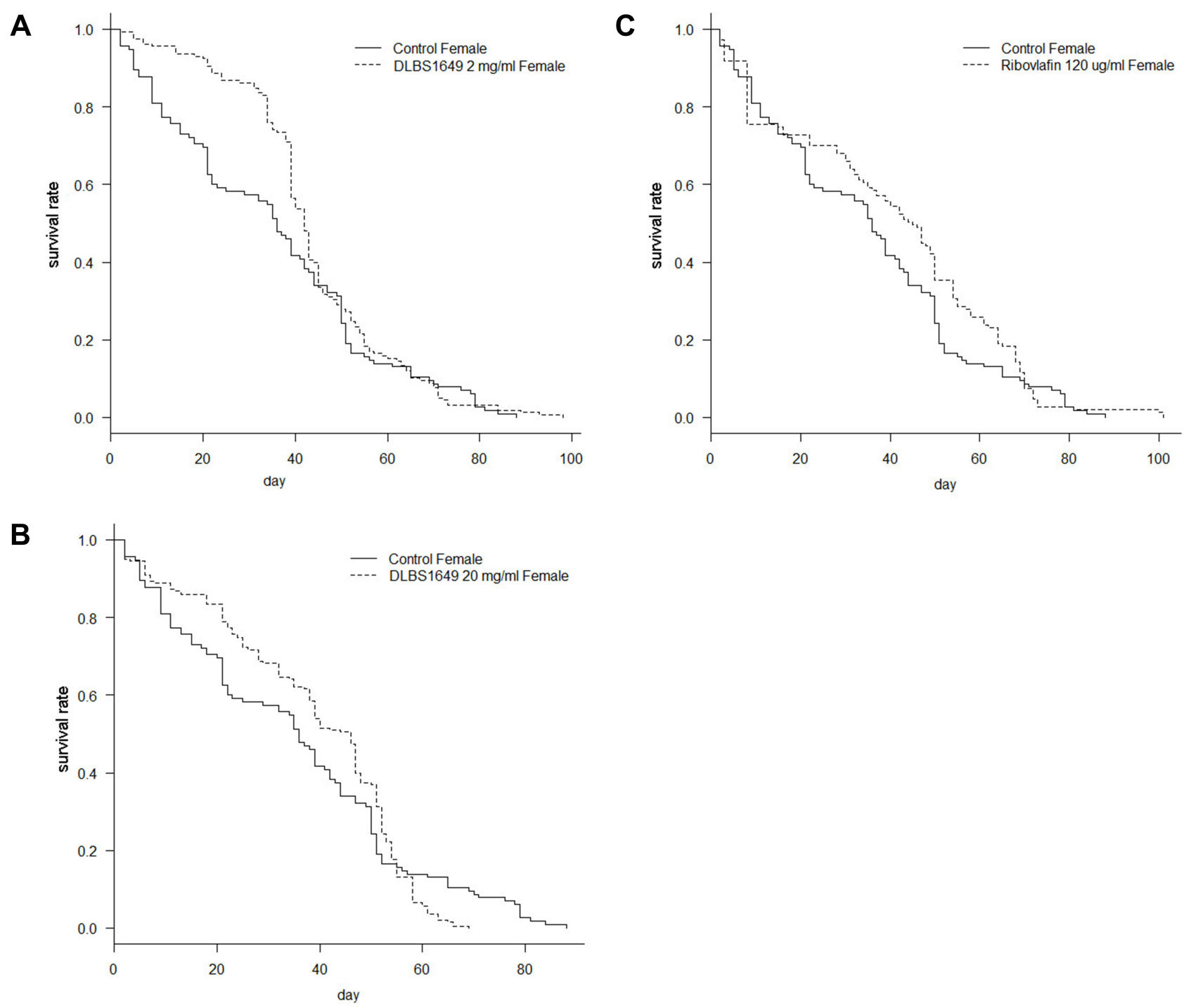

Figure 10 Survival rate of female Drosophila melanogaster following treatment with DLBSI 649 and riboflavin. (A) Treatment with $2 \mu g / \mathrm{mL}$ DLBSI649. (B) Treatment with 20 $\mu \mathrm{g} / \mathrm{mL}$ DLBSI649. (C) Treatment with $120 \mu \mathrm{g} / \mathrm{mL}$ riboflavin.

the muscles and result in a metabolism disorder. Calorie restriction's role in antiaging is also supported by another study, in which it increased SIRT1 metabolism in adipocyte tissue. ${ }^{74}$ Further studies on DLBS1649 and calorie restriction, whether through $\mathrm{mTOR}$ or other pathways, are still needed. The calorie-restriction observation corroborated the notion that DLBS1649 has antiaging activity.

Our research on DLBS1649's antiaging properties was complemented by survival data on D. melanogaster. D. melanogaster sex influenced survival rate. Male D. melanogaster had higher survival rates than females. Male flies in general were not significantly affected by the administration of riboflavin $120 \mu \mathrm{g} / \mathrm{mL}$ or DLBS1649at either concentration. Different results were seen in female flies, which showed a significant influence of DLBS1649 treatment at 2 $\mathrm{mg} / \mathrm{mL}$ and $20 \mathrm{mg} / \mathrm{mL}$. Increased RMST was seen in females: $23.87 \%$ (DLBS1649 $2 \mathrm{mg} / \mathrm{mL}$ ) and $15.62 \%$ (DLBS1649 $20 \mathrm{mg} / \mathrm{mL}$ ). This also indicated that lower concentration of DLBS1649 $(2 \mathrm{mg} / \mathrm{mL})$ was better than the higher one $(20 \mathrm{mg} / \mathrm{mL})$. Riboflavin also increased RMST in female D. melanogaster; however, this was not statistically significant. On the other hand, lower mortality rates over certain periods were observed. DLBS1649-treated D. melanogaster (male and female) had lower mortality rates than controls for days 20-50. Male flies showed lower mortality rates compared to controls within 30-60 days, with a similar result for female flies within 20-50 days. Sex affected mortality rates also. Decreasing mortality rates in female $D$. melanogaster was earlier observed than in males. Riboflavin did not showed positive effects on male flies. 

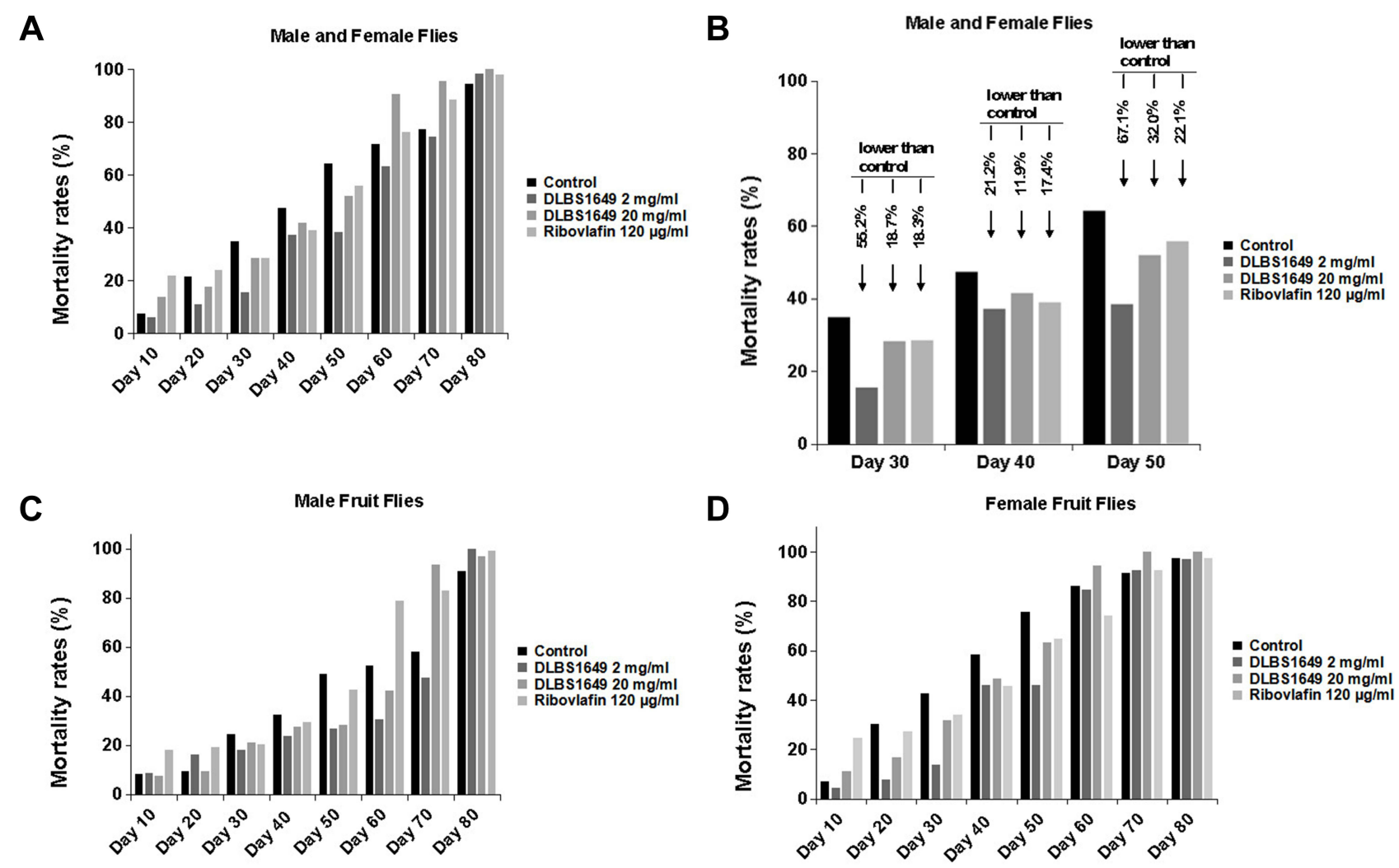

Figure I I Effect of DLBSI 649 on mortality rates in total, male, and female Drosophila melanogaster. Mortality rates for each group were calculated every 10 days until day 80. (A) Mortality rate of D. melanogaster (male and female) treated with DLBSI649 2 and $20 \mathrm{mg} / \mathrm{mL}$. (B) Mortality rates at day 30,40 , and 50 of D. melanogaster treated with DLBSI $6492 \mathrm{mg} / \mathrm{mL}$. (C) Mortality rate of male flies treated with DLBSI649 2 and $20 \mathrm{mg} / \mathrm{mL}$. (D) Mortality rate of female flies given DLBSI649 2 and $20 \mathrm{mg} / \mathrm{mL}$.

Zou et $\mathrm{al}^{38}$ found that riboflavin increased the survival of male $D$. melanogaster. The difference in results might be due to differences in site conditions and methods.

\section{Conclusion}

In this study, DLBS1649 prevented telomere shortening, contained TERT activity, and induced CMYC expression. $S I R T$ and $K L$, which are indicators of antiaging were also affected by DLBS1649, with smaller decrease in expression of SIRT1, SIRT2, and KL thancontrols within the same time frame. Another interesting result was the additional effect of calorie restriction, support DLBS1649's antiaging properties, though further study on fat-metabolism pathways is needed. A more important result is that TP53 expression was not increased significantly by DLBS1649 administration. This showed that DLBS1649 can act as an antiaging agent with no tumorigenic risk. Although, the effect of increasing survival was only significant in female D. melanogaster, increaed RMST was seen in both male and female flies treated with DLBS1649 $2 \mathrm{mg} / \mathrm{mL}$. Further research is needed, especially to investigate potential mechanisms of calorie restriction and in vivo efficacy in higher organisms. However, this study indicated that DLBS1649 has good potential to be developed as a future antiaging agent.

\section{Abbreviations}

ORO, Oilred O; RMST, restricted mean survival time; $\mathrm{C}_{\mathrm{T}}$, cycle threshold; $\mathrm{R}_{\mathrm{f}}$, retention factor.

\section{Acknowledgments}

This research was fully supported by Dexa Medica. The authors would like to thank Irfan Agustian Darfiansyah for preparing DLBS1649, Yulita Ika Sari and Tia Mariana for their contribution to the cell-culture work, and Professor Maggy T. Suhartono and Kharisma Setianingrum Agpri for their assistance in editing the manuscript.

\section{Disclosure}

All authors were employees of Dexa Medica at the time of the study. The authors report no other potential conflicts of interest in this work. 


\section{References}

1. Argyropoulou A, Aligiannis N, Trougakos IP, et al. Natural compounds with anti-ageing activity. Nat Prod Rep. 2013;30:1412-1437. doi:10.1039/c3np70031c

2. Wong KK, Maser RS, Bachoo RM, et al. Telomere dysfunction and Atm deficiency compromises organ homeostasis and accelerates aging. Nature. 2003;421(6923):643-648. doi:10.1038/nature01385

3. Ideker T, Thorsson V, Ranish JA, et al. Integrated genomic and proteomic analysis of a systematically perturbed metabolic network. Science. 2001;292(5518):929-934. doi:10.1126/science.292.5518. 929

4. Sniderman AD, Furberg CD. Age as a modifiable risk factor for cardiovascular disease. Lancet. 2008;371(9623):1547-1549. doi:10.1016/S0140-6736(08)60313-X

5. Shen CY, Jiang JG, Li Yang L, et al. Anti-ageing active ingredients from herbs and nutraceuticals used in traditional Chinese medicine: pharmacological mechanisms and implications for drug discovery. $\mathrm{Br}$ J Pharmacol. 2017;174(11):1395-1425. doi:10.1111/bph.13631

6. Muraki K, Nyhan K, Han L. Mechanisms of telomere loss and their consequences for chromosome instability. Front Oncol. 2012;135 (2): 13 .

7. Finkel T, Serrano M, Blasco MA. The common biology of cancer and ageing. Nature. 2007;448(7155):767-774. doi:10.1038/nature05985

8. Chan S, Blackburn EH. Telomeres and telomerase. Philos Trans $R$ Soc Lond B-Biol Sci. 2004;359(1441):109-121. doi:10.1098/ rstb.2003.1370

9. Blackburn EH. Switching and signaling at the telomere. Cell. 2001;106(6):661-673. doi:10.1016/S0092-8674(01)00492-5

10. Oberdoerffer P, Sinclair DA. The role of nuclear architecture in genomic instability and ageing. Nat Rev Mol Cell Biol. 2007;8 (9):692-702. doi:10.1038/nrm2238

11. Westphal CH, Dipp MA, Guarente L. A therapeutic role for sirtuins in diseases of aging? Trends Biochem Sci. 2007;32(12):555-560. doi:10.1016/j.tibs.2007.09.008

12. Tjandrawinata RR, Arifin PF, Tandrasasmita OM, Rahmi D, Aripin A. DLBS1425, a Phaleria macrocarpa (Scheff.) Boerl. extract confers anti proliferative and proapoptotic effects via eicosanoid pathway. $J$ Exp Ther Oncol. 2010;8(3):187-201.

13. Tjandrawinata RR, Nofiarny D, Susanto LW, Hendri P, Clarissa A. Symptomatic treatment of premenstrual syndrome and/or primary dysmenorrhea with DLBS1442, a bioactive extract of Phaleria macrocarpa. Int J Gen Med. 2011;4:465.

14. Tjandrawinata RR, Suastika K, Nofiarny D. DLBS3233 extract, a novel insulin sensitizer with negligible risk of hypoglycemia: a phase-I study. Int J Diabetes Metab. 2012;21:13-20. doi:10.1159/ 000497721

15. Tjandrawinata RR, Nailufar F, Arifin PF. Hydrogen potassium adenosine triphosphatase activity inhibition and downregulation of its expression by bioactive fraction DLBS2411 from Cinnamomum burmannii in gastric parietal cells. Int $J$ Gen Ed. 2013;6:807. doi:10.2147/IJGM.S50134

16. Karsono AH, Tandrasasmita OM, Tjandrawinata RR. Bioactive fraction from Lagerstroemia speciosa leaves (DLBS3733) reduces fat droplet by inhibiting adipogenesis and lipogenesis. $J$ Exp Pharmacol. 2019;11:39. doi:10.2147/JEP.S181642

17. Tolkah NM. Genetic variation of Centella asiatica based on randomly amplified polymorphic DNA. Ethnobot J. 1999;22:7-13.

18. Brinkhaus B, Lindner M, Schuppan D, et al. Chemical, pharmacological, and clinical profile of the East Asian medicinal plant. Centella Asiatica Phytomedicine. 2000;7(5):427-448. doi:10.1016/S09447113(00)80065-3

19. James JT, Dubery IA. Pentacyclic triterpenoids from the medicinal herb, Centella asiatica (L.) Urban. Molecules. 2009;14(10):39223941. doi:10.3390/molecules14103922
20. Tenni R, Zanaboni G, De Agustini MP, et al. Effect of the triterpenoids fraction of Centella asiatica on macromolecules of the connective matrix in human skin fibroblast cultures. Ital $J$ Biochem. 1988;37(2):69-77.

21. Bonte F, Dumas M, Chaudagne C, et al. Influence of asiatic acid, madecassic acid and asiaticoside on human collagen I synthesis. Planta Med. 1994;60(2):133-135. doi:10.1055/s-2006-959434

22. Maquart FX, Chasting F, Simeon A, et al. Triterpenes from Centella asiatica stimulate extracellular matrix accumulation in rat experimental wounds. Eur J Dermatol. 1999;9(4):289-296.

23. Kim WJ, Kim JD, Veriansyah B, Kim J, Oh SG, Tjandrawinata RR. Extraction of Asiaticoside from Centella asiatica: effects of solvents and extraction methods. Biochemistry. 2004;23:339-344.

24. Gupta YK, Kumar MHV, Srivastava AK. Effect of Centella asiatica on pentylenetetrazole-induced kindling, cognition, and oxidative stress in rats. Pharmacol Biochem Behav. 2003;74(3):579-585. doi:10.1016/S0091-3057(02)01044-4

25. Rao SB, Chetana M, Uma DP. Centella asiatica treatment during postnatal period enhances learning and memory in mice. Physiol Behav. 2005;86(4):449-457. doi:10.1016/j.physbeh.2005.07.019

26. Chen Y, Han T, Rui Y, et al. Effects of total triterpenes of Centella asiatica on the Depression behavior and concentration of amino acid in forced swimming mice. Zhong Yao Cai. 2003;26(12):870-873.

27. Fitrawan LO, Ariastuti R, Tjandrawinata RR, Nugroho AE, Pramono $S$. Antidiabetic effect of combination of fractionated-extracts of Andrographis paniculata and Centella asiatica: in vitro study. Asian Pac J of Trop Biomed. 2018;8(11):527. doi:10.4103/2221-1691.245957

28. Parvathi D, Amritha A, Paul SFD. Wonder animal model for genetic studies-Drosophila melanogaster-its life cycle and breeding methods-a review. Sri Ramanchandra J Med. 2009;2:33-38.

29. Panchal K, Tiwari AK. Drosophila melanogaster "a potential model organism" for identification of pharmacological properties of plants/ plant-derived components. Biomed Pharmacother. 2017;89:1331-1345.

30. Jafari M. Drosophila melanogaster as a model system for the evaluation of anti-aging compounds. Fly. 2010;4(3):253-257. doi:10.4161/ fly.4.3.11997

31. Walter MF, Biessmann MR, Benitez C, Török T, Mason JM, Biessmann H. Effects of telomere length in Drosophila melanogaster on life span, fecundity, and fertility. Chromosoma. 2007;116(1):4151. doi:10.1007/s00412-006-0081-5

32. Capkova FR, Biessmann H, Mason JM. Regulation of telomere length in Drosophila. Cytogenet Genome Res. 2008;122(3-4):356364. doi:10.1159/000167823

33. George JA, DeBaryshe PG, Traverse KL, Celniker SE, Pardue ML. Genomic organization of the Drosophila telomere retrotransposable elements. Genome Res. 2006;16(10):1231-1240. doi:10.1101/ gr.5348806

34. Kim JH, Hwang KH, Park KS, et al. Biological role of anti-aging protein klotho. $J$ Lifestyle Med. 2015;5(1):1-6. doi:10.15280/ jlm.2015.5.1.1

35. Morrison S, McGee SL. 3T3-L1 adipocytes display phenotypic characteristics of multiple adipocyte lineages. Adipocyte. 2015;4(4):295302. doi: $10.1080 / 21623945.2015 .1040612$

36. O'Callaghan N, Dhillon V, Thomas P, Fenech M. A quantitative realtime PCR method for absolute telomere length. Biotechniques. 2008;44(6):807-809. doi:10.2144/000112761

37. Cawthon RM. Telomere measurement by quantitative PCR. Nucleic Acids Res. 2002;30(10):e47. doi:10.1093/nar/30.10.e47

38. Zou YX, Ruan MH, Luan J. Anti-aging effect of riboflavin via endogenous antioxidant in fruit fly Drosophila melanogaster. J Nutr Health Aging. 2017;21(3):314-319. doi:10.1007/s12603-016-0752-8

39. Altman DG. Practical Statistics for Medical Research. Chapman and Hall; 1991.

40. Uno H, Claggett B, Tian L. Moving beyond the hazard ratio in quantifying the between-group difference in survival analysis. $J$ Clin Oncol. 2014;32(22):2380-2385. doi:10.1200/JCO.2014.55.2208 
41. Meeran MFN, Goyal SN, Suchal K, et al. Pharmacological properties, molecular mechanisms, and pharmaceutical development of asiatic acid: a pentacyclic triterpenoid of therapeutic promise. Front Pharmacol. 2018;4(9):892.

42. Kamble SM, Patel HM, Goyal SN, et al. In-silico evidence for binding of pentacyclic triterpenoids to Keap1-Nrf2 protein-protein binding site. Comb Chem High Throughput Screen. 2017;20 (3):215-234. doi:10.2174/1386207319666161214111822

43. Kamble SM, Goyal SN, Patil CR. Multifunctional pentacyclic triterpenoids as adjuvants in cancer chemotherapy: a review. RSC Adv. 2014;4:33370-33382. doi:10.1039/C4RA02784A

44. Lokanathan Y, Omar N, Puzi NNA, et al. Recent updates in neuroprotective and neuroregenerative potential of Centella asiatica. Malays J Med Sci. 2016;23(1):4-14.

45. Soumyanath A, Zhong YP, Gold SA, et al. Centella asiatica accelerates nerve regeneration upon oral administration and contains multiple active fractions increasing neurite elongation in vitro. $J$ Pharm Pharmacol. 2005;57(9):1221-1229. doi:10.1211/jpp.57.9.0018

46. Tiwari S, Singh S, Patwardhan K, et al. Effect of Centella asiatica on mild cognitive impairment (MCI) and other common age-related clinical problems. Dig J Nanomater Biostruct. 2008;3(4):215-220.

47. Bylka W, Znajdek-wiżeń P, Studzińska-Sroka E, et al. Centella asiatica in cosmetology. Postep Derm Alergol. 2013;1:46-49.

48. James J, Dubery I. Identification and quantification of triterpenoid Centelloids in Centella asiatica (L.) urban by densitometric TLC. $J$ Planar Chromatogr. 2011;24:82-87. doi:10.1556/JPC.24.2011.1.16

49. Guo L, Wei XD, Ou Q, et al. Effect of astragaloside on the expression of telomerase activity and klotho gene in aged HELF cells. Chin J Gerontol. 2010;13:1819-1822.

50. Salvador L, Singaravelu G, Calvin B, et al. A natural product telomerase activator lengthens telomeres in humans: a randomized, double-blind, and placebo-controlled study. Rejuvenation Res. 2016;19 (6):478-484. doi:10.1089/rej.2015.1793

51. Guruprasad KP, Dash S, Marigowda B, et al. Influence of Amalaki Rasayana on telomerase activity and telomere length in human blood mononuclear cells. J Ayurveda Integr Med. 2017;8(2):105-112. doi:10.1016/j.jaim.2017.01.007

52. Wu KJ, Grandori C, Amacker M, et al. Direct activation of TERT transcription by c-MYC. Nat Genet. 1999;21(2):220-224. doi:10.1038/6010

53. Shay JW. Role of telomeres and telomerase in aging and cancer. Discov. 2016;6(6):584-593.

54. Mazucanti CH, Cabral-Costa JV, Vasconcelos AR, et al. Longevity pathways (mTOR, SIRT, Insulin/IGF-1) as key modulatory targets on aging and neurodegeneration. Curr Top Med Chem. 2015;15 (21):2116-2138. doi:10.2174/1568026615666150610125715

55. Oliveira RM, Sarkander J, Kazantsev AG, et al. SIRT2 as a therapeutic target for age-related disorders. Front Pharmacol. 2012;3 (82):1-9. doi:10.3389/fphar.2012.00082

56. Xu MF, Xiong YY, Liu JK, et al. Asiatic acid, a pentacyclic triterpene in Centella asiatica, attenuates glutamate-induced cognitive deficits in mice and apoptosis in SH-SY5Y cells. Acta Pharmacol Sin. 2012;33(5):578-587. doi:10.1038/aps.2012.3

57. Qian Y, Xin Z, Lv Y, et al. Asiatic acid suppresses neuroinflammation in BV2 microglia via modulation of the Sirt1/NF- $\kappa \mathrm{B}$ signaling pathway. Food Funct. 2018;9(2):1048-1057. doi:10.1039/C7FO01442B
58. Han YY, Shen P, Hao J, et al. Ganoderma lucidum polysaccharides improve renal aging through upregulating SIRT1 expression. Int $J$ Clin Exp Med. 2018;11(7):6816-6823.

59. Sung B, Chung JW, Bae HR, et al. Humulus japonicus extract exhibits anti-oxidative and anti-aging effects via modulation of the AMPK-SIRT1 pathway. Exp and Ther Med. 2015;9(5):1819-1826. doi:10.3892/etm.2015.2302

60. Kou X, Liu X, Chen X, et al. Ampelopsin attenuates brain aging of D-gal-induced rats through miR-34a-mediated SIRT1/mTOR signal pathway. Oncotarget. 2016;7(46):74484-74495. doi:10.18632/ oncotarget. 12811

61. Viswanathan M, Kim SK, Berdichevsky A, et al. A role for SIR-2.1 regulation of ER stress response genes in determining Celegans life span. Dev Cell. 2005;9(5):605-615. doi:10.1016/j.devcel.2005.09. 017

62. Zhou X, Yang Q, Xie Y, et al. Tetrahydroxystilbene glucoside extends mouse life span via upregulating neural klotho and downregulating neural insulin or insulin-like growth factor 1. Neurobiol Aging. 2015;36(3):1462-1470. doi:10.1016/j.neurobiolaging.2014. 11.002

63. Liang Y, Liu C, Lu M, et al. Calorie restriction is the most reasonable anti-ageing intervention: a meta-analysis of survival curves. Sci Rep. 2018;8(1):5779. doi:10.1038/s41598-018-24146-Z

64. Al-Regaiey KA. The effects of calorie restriction on aging: a brief review. Eur Rev Med Pharmacol Sci. 2016;20(11):2468-2473.

65. López-Lluch G, Navas P. Calorie restriction as an intervention in ageing. J Physiol. 2016;594(8):2043-2060. doi:10.1113/JP270543

66. Blagosklonny MV. Koschei the immortal and anti-aging drugs. Cell Death Dis. 2014;5(12):e1552. doi:10.1038/cddis.2014.520

67. Chang GR, Chiu YS, Wu YY, et al. Rapamycin protects against highfat diet-induced obesity in C57BL/6J mice. J Pharmacol Sci. 2009;109(4):496-503. doi:10.1254/jphs.08215FP

68. Chang GR, Wu YY, Chiu YS, et al. Long-term administration of rapamycin reduces adiposity but impairs glucose tolerance in high-fat diet-fed KK/H1J mice. Basic Clin Pharmacol Toxicol. 2009;105 (3):188-198. doi:10.1111/j.1742-7843.2009.00427.x

69. Komarova EA, Antoch MP, Novototskaya LR, et al. Rapamycin extends lifespan and delays tumorigenesis in heterozygous p53 mice. Aging. 2012;4(10):709-714. doi:10.18632/aging.100498

70. Miller RA, Harrison DE, Astle CM, et al. Rapamycin, but not resveratrol or simvastatin, extends life span of genetically heterogeneous mice. J Gerontol a Biol Sci Med Sci. 2011;66(2):191-201. doi:10.1093/gerona/glq178

71. Harrison DE, Strong R, Sharp ZD, et al. Rapamycin fed late in life extends lifespan in genetically heterogeneous mice. Nature. 2009;460 (7253):392-395. doi:10.1038/nature08221

72. Miller KN, Burhans MS, Clark JP, et al. Aging and caloric restriction impact adipose tissue, adiponectin, and circulating lipids. Aging Cell. 2017;16(3):497-507. doi:10.1111/acel.12575

73. Kim JY, Kim DH, Choi J, et al. Changes in lipid distribution during aging and its modulation by calorie restriction. Age. 2009;12:127142. doi:10.1007/s11357-009-9089-0

74. Xu C, Cai Y, Fan P, et al. Calorie restriction prevents metabolic aging caused by abnormal SIRT1 function in adipose tissue. Diabetes. 2015;64(5):1576-1590. doi:10.2337/db14-1180
Journal of Experimental Pharmacology

\section{Publish your work in this journal}

The Journal of Experimental Pharmacology is an international, peerreviewed, open access journal publishing original research, reports, reviews and commentaries on all areas of laboratory and experimental pharmacology. The manuscript management system is completely online and includes a very quick and fair peer-review system. Visit $\mathrm{http} / / / \mathrm{www}$. dovepress.com/testimonials.php to read real quotes from published authors. 